Egyptian Journal of Rabbit Science, 27 (2): 219- 244(2017)

\title{
EFFECTS OF SUPPLEMENTAL FEEDING WITH SOME MEDICINAL PLANTS ON SEMEN CHARACTERISTICS, BLOOD METABOLITES AND HISTOLOGY OF SELECTED ORGANS OF NEW ZELAND MALE RABBITS IN NORTH SINAI
}

\author{
M. M. Shetaewi "; Bakr, E. O. A. "; Mousa, M. R. M. "; Abdel-Samee, A. \\ M. "; Ahmed, A. A. " and Ibrahim, I. M. M. \\ * Department of Animal and Poultry Production, College of Environmental \\ Agricultural Sciences, Al-Arish University, Egypt. \\ ** Department of Cytology and Histology, College of Veterinary Medicine, \\ Suez Canal University, Egypt.
}

Twenty five New Zealand White (NZW) rabbit bucks, (aged 9 months and weighed $3.28 \pm 0.1 \mathrm{~kg}$ ) were divided randomly into five comparable groups (5 each).Rabbits in the 1st group were fed pelleted control dietwithout medicinal plants (CO), while those in the 2nd, 3rd, 4 th and 5th groups were fed the pelleted diet containing $3 \%$ rosemary $(R S), 3 \%$ marjoram $(M R), 1.5 \%$ ginger root $(Z R)$ and $2.5 \%$ mixture $(M X)$ of these medicinal plants, respectively.

Results showed that rabbit bucks of the ZR group had lower $(P<0.05)$ blood glucose level compared with the control, but did not differ significantly from the other treatments. Serum total protein increased $(P<0.05)$ in $R S, M R$ and $M X$ when compared with control group, but $Z R$ did not differ significantly from the control. Mean concentrations of serum albumin (AL) and AL/GL ratio did not differ significantly due to treatments. Rabbit fed diets containing rosemary, marjoram, ginger or their mixture showed lower $(P<0.05)$ concentrations of plasma triglycerides than those fed the control diet. Rabbit fed $Z R$ and $M X$ had the lowest $(P<0.05)$ level of cholesterol concentration, compared with for $C O, R S$ and MR groups. Serum testosterone levels were significantly $(P \leq 0.05)$ higher in rabbit bucks of $Z R$ and $M X$ groups compared with $C O, R S$ and $M R$, respectively.Semen Ejaculate volume was significantly higher in $M R, Z R$ and $M X$ groups compared with the control but $R S$ group did not differ significantly from the control. Means of mass motility were higher $(P \leq 0.05)$ in treatment groups of $R S, Z R$ and MX than the control but MR group did not differ from the control. The effect of dietary treatment on sperm cell concentration was significant. The ZR group had the highest mean followed by $M X, R S, C O$ and MR groups. The histological examination 
of testicular sections showed that the elongated spermatids were more apparent in the ZR group and Leyding cells were well-developed in the $M X$ group. The histological examination of liver sections showed marked increase in the size and number of bile ducts and many bi-nucleated hepatocytes and sinusoidal dilatation appeared in RS group. MR group showed an increase in the number of bile ducts, mononuclear phagocytic cells and sinusoid dilatation was observed. ZR group showed a lymphocytic infiltration was surrounding the bile duct and increase in the number of Kupffer cells. In MX group no magnificent changes were observed except that dilatation of the bile duct also no change in the sinusoidal size was observed. The histological examination of kidney sections of different experimental groups showed a congestion of some blood vessels in the MR, ZR and MX groups.

Conclusively, the medicinal plants, Rosemary (Rosmarinus officinalis), Marjoram (Origanum majorana), Ginger root (Zingiber officinale) and their mixture could be added to NZW rabbit diets within the limits recorded in this study to improve semen characteristics and reproductive performance of NZW rabbit bucks without any detrimental effects on their health.

Keywords: Rabbits, medicinal plants, Rosemary, Marjoram, Ginger, blood, semen characteristics, reproduction, hormones, testosterone, histology, testis, liver, kidney, Sinai.

Compared to other larger domestic species, rabbits have many advantages; including high reproductive rates, rapid growth rates, use of noncompetitive feeds and simple housing requirements (Cheeke, 1987). Therefore, rabbits can be raised in Egypt to fulfil part of our requirements of animal protein. Non-traditional feed sources such as medicinal plants, crop residues and agro-industrial by-products must be searched in order to decrease the gap between the available and the requirements of animal feedstuffs. It is important to use natural substances such as medicinal plants that have no adverse effects on animal and human health (Abdel-Malek et al., 1995; Abaza and El-Said, 2005). Medicinal plants can be used as growth promoters and could improve the reproductive performance of rabbits. Medicinal plants and herbs can also increase resistance to disease via optimizing the function of the immune system (Amakye-Anim et al., 2000 and Al-Beitawi et al., 2010), and antioxidant activity (Mericili, 1990 and Tipu, et al., 2006). 
Therefore, this study was carried out to evaluate the effects of some dried medicinal plants such as Rosemary (Rosmarinus officinalis L.), Marjoram (Origanum majorana L.) and Ginger root (Zingiber officinale L.) on semen characteristics, blood metabolites and histology of some organs of New Zealand White rabbit males under North Sinai conditions.

\section{MATERIALS AND METHODS}

The present study was carried out at the Rabbitry Farm, Department of Animal and Poultry Production, Faculty of Environmental Agricultural Sciences, Al-Arish University, North Sinai, Egypt. Experiments were conducted in Summer and Fall seasons of 2014 (July through November).

A total of 25 New Zealand white (NZW) male rabbits (9 month. old, $3.28 \mathrm{~kg}$ ) was used in this study. Three medicinal plants from North Sinai spices markets were used in this study as follows: Rosemary (Rosmarinus officinalis L.), Marjoram (Origanum majorana L.), Ginger root (Zingiber officinale L.). These medicinal plants were grinded and then mixed with the diet. Five experimental diets were formulated to cover the nutrient requirements for rabbits according to NRC (1977). At the beginning of the experiment, male rabbits were randomly allotted into five equal groups ( 5 rabbits each). Rabbits in the control group (CO) were fed the control diet without medicinal plants. The $2^{\text {nd }}, 3^{\text {rd }}, 4^{\text {th }}$ and $5^{\text {th }}$ groups were fed pelleted diet containing $3 \%$ rosemary, $3 \%$ marjoram, $1.5 \%$ ginger root and $2.5 \%$ mixture (1.5\% rosemary, $1.5 \%$ marjoram, $0.5 \%$ ginger root) of these medicinal plants, respectively.

Rabbits were clinically examined and found to be healthy and free of external and internal parasites. They were kept under the same managerial and hygienic conditions. The rabbits were housed in galvanized wire cages in a well-ventilated houses and were fed a pelleted diet ad lib during the whole experimental period. The ingredients and the approximate analysis of the pelleted diet are shown in Table 1. Chemical analysis was carried out for medicinal plants and for diet samples according to A.O.A.C. methods (1995). Chemical analysis of medicinal plants and experimental diets are presented in Table 2. All animals received fresh water containing $705 \mathrm{ppm}$ total dissolved solids (TDS) which was available automatically all the time by stainless steel nipples.

At the end of the experimental period (12 month. of age), three rabbit bucks from each treatment group were chosen randomly, kept off feed overnight and were slaughtered next morning. Blood samples were collected into centrifuge tubes and allowed to clot at room temperature for $30 \mathrm{~min}$. 
Table 1. Ingredients of experimental diets used in this study.

\begin{tabular}{|c|c|}
\hline Ingredients & Control diet \\
\hline Alfalfa hay & 30.00 \\
\hline Wheat bran & 29.00 \\
\hline Yellow corn & 12.50 \\
\hline Soybean meal (44\%) & 14.00 \\
\hline Barley grain & 10.00 \\
\hline Molasses & 2.00 \\
\hline Calcium carbonate (lime stone) & 0.60 \\
\hline Sodium chloride (salt) & 0.30 \\
\hline Vitamins \& Mineral Premix* & 0.30 \\
\hline DL-Methionine & 0.10 \\
\hline Di-Calcium phosphate & 1.20 \\
\hline Total & 100.00 \\
\hline \multicolumn{2}{|l|}{ Calculated chemical composition } \\
\hline Crude protein $(\mathrm{CP})$ & 18.128 \\
\hline Ether extract (EE) & 2.936 \\
\hline Crude fiber (CF) & 12.17 \\
\hline Digestible energy $(\mathrm{Kcal} / \mathrm{Kg}) *$ & 2768.3 \\
\hline \multicolumn{2}{|c|}{ 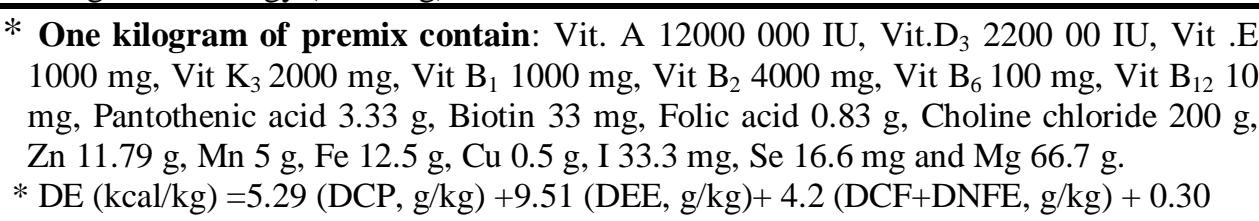 } \\
\hline
\end{tabular}

Table 2. Chemical analysis (\%) of medicinal plants and the experimental diets.

\begin{tabular}{ccclllll}
\hline \multirow{2}{*}{ Items } & \multirow{2}{*}{ DM } & \multicolumn{7}{c}{ \% DM basis } \\
\cline { 3 - 8 } & & OM & CP & EE & CF & NFE & ASH \\
\hline Rosemary & 91.69 & 94.59 & 4.13 & 11.64 & 13.37 & 65.45 & 5.41 \\
Marjoram & 91.41 & 84.22 & 14.18 & 4.14 & 15.22 & 50.68 & 15.78 \\
Ginger root & 90.12 & 94.34 & 9.38 & 4.04 & 11.28 & 69.64 & 5.66 \\
\hline \multicolumn{6}{l}{ Chemical composition of the experimental diets fed to } & NZW rabbits. \\
CO & 91.89 & 89.42 & 18.21 & 3.04 & 12.05 & 56.12 & 10.58 \\
RS & 92.34 & 89.58 & 17.79 & 3.29 & 12.09 & 56.39 & 10.43 \\
MR & 92.33 & 89.26 & 18.09 & 3.07 & 12.15 & 55.96 & 10.74 \\
ZR & 90.95 & 89.65 & 17.81 & 3.01 & 11.86 & 55.48 & 10.35 \\
\hline MX & 91.87 & 89.75 & 17.45 & 3.05 & 11.74 & 54.59 & 10.25 \\
\hline
\end{tabular}

$\mathrm{CO}$; control, pelleted diet.RS; pelleted diet containing $3 \%$ rosemary.

MR; pelleted diet containing 3\% marjoram.ZR; pelleted diet containing $1.5 \%$ ginger roots.

MX; Mixture, pelleted diet containing $1 \%$ rosemary $+1 \%$ marjoram $+0.5 \%$ ginger root 
Serum was then separated by centrifugation at $3000 \mathrm{rpm}$ for $15 \mathrm{~min}$ and was subsequently decanted into glass vials and stored at $-20^{\circ} \mathrm{C}$ until it was analyzed (Shetaewi, 1998). Concentration of serum total protein (Henry and Cannon, 1974), albumin, glucose, and cholesterol (Deutsche Veterina ermedizinische Gesellschaft, 1976) were assessed. Activity of aspartate transaminases (AST) and alanine transaminases (ALT) were determined (Reitman and Franke, 1957). Creatinine, and urea nitrogen (UN) were analyzed using assay commercial kits supplied by biomed (Germany), spinreact (Spain) and randox (England). Serum globulin was obtained by difference (Total protein minus albumin ) and albumin/ globulin (alb/glob) ratio was also calculated. Blood serum testosterone concentration was assessed using RIA technique utilizing Coat-Ab-Count Kits (Diagnostic Production Corporation, Los Angeles, USA) according to Abraham (1977).

At 10 moths, semen was collected twice-weekly using artificial vagina. Physical semen characteristics were evaluated in the fresh collected semen.Ejaculate volume $(\mathrm{ml})$ and Initial mass motility of raw semen were estimated as described by Melrose and Loing (1970).Assessment of live/dead spermatozoa percentage was performed according to (Blom, 1950) .Percentage of abnormal spermatozoa was determined in smear prepared for live/dead sperm test. A weak eosin solution (Smith and Mayer, 1955) was used for evaluation of sperm cell concentration. Spermatozoa were counted microscopically by the improved Neubauer Haemocytometer slide $(\mathrm{GmbH}$ and co., Brandstwiete 4, 200 Hamburg 11, Germany). Total sperm output (TSO) per ejaculate (x 106/ejaculate) was calculated by multiplying semen ejaculate volume and semen concentration $/ \mathrm{ml}$. Live normal sperm output (x $10^{6}$ ). Live normal sperm output/ejaculate (LNSO) was calculated according to

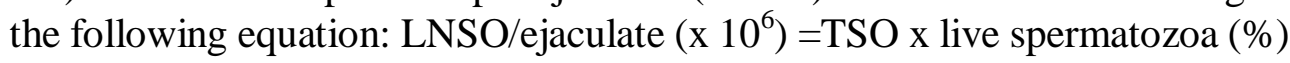
$\mathrm{x}$ normal spermatozoa (\%).

Buck rabbits were slaughtered at 13 monthof age and specimens of liver, kidney and testes were taken and prepared for histological examination according to Bancroft and Stevens (1990).

Data were analyzed by Least - Squares Analysis Of Variance using the General linear model (GLM) procedure of SAS (2004) according to Steel and Torrie (1980). Semen characteristics were analyzed by repeated measures analysis of variance (split-plot; Gill, 1978).

\section{RESULTS AND DISCUSSION}

\section{Serum metabolites and hormones.}

Rabbits of the ZR group had lower $(\mathrm{P}<0.05)$ serum glucose level compared to the control $(\mathrm{CO})$ but did not differ significantly from the other 
treatment groups (Table3). Ginger is supposed to be a hypoglycemic substance since ginger supplementation decreased serum glucose and increased insulin (Ghlissi et al., 2012 and Hafez, 2010). The extracts of ginger reduced blood glucose in rabbits (Mascolo, 1989). The important active components of the ginger root are phenol compounds which have hypoglycemic activity (Zancan et al., 2002).In rabbits, Bakırel et al., (2008) demonstrated that the Rosmarinusofficinalis extract exerts remarkable hypoglycaemic and antihyperglycaemic activity due to its possible multiple effects involving both pancreatic and extra-pancreatic mechanism. Ibrahim (2010) found that feeding diets containing ginger and thyme to growing NZW rabbits decreased $(\mathrm{P}<0.05)$ serum glucose.

Results showed that serum total protein $(\mathrm{TP})$ increased $(\mathrm{P}<0.05)$ in RS, MR and MX when compared with control group (Table3). The importance of increasing total TP is due to the fact that it generates a colloid osmotic pressure, which control the flow of water between blood and interstitial fluids (Harper et al., 1977). Also, Haider et al., (2010) and El-khashab et al., (2011) reported that proteins are playing a role as intracellular buffers within body tissues to provide a reserve buffering capacity.Mean concentrations of serum albumin (AL) and AL/GL ratio did not differ significantly due to treatments. Albumin, rather than total protein or globulin, has been shown to be the most sensitive indicator of protein status (Kirsch et al., 1968; Sykes and Field, 1973 and Shetaewi and Ross, 1991, Shetaewi, 1998). There was a tendency of higher concentrations of serum GL in rabbits fed RS, MR, ZR and MX than those fed CO (Table3). Ibrahim (2010) used some medicinal plants and found that, feeding diets containing ginger and thyme to growing NZW rabbits increased $(\mathrm{P}<0.05)$ total protein, albumin and globulin in blood.

Rabbit fed diets containing rosemary (RS), marjoram (MR), ginger $(\mathrm{ZR})$ or their mixture $(\mathrm{MX})$ showed lower $(\mathrm{P}<0.05)$ concentrations of serum triglycerides than those fed the control diet (Table3).Rabbit fed ZR and MX had the lowest $(\mathrm{P}<0.05)$ level of cholesterol concentration $(60.7$ and 53.0 $\mathrm{mg} / \mathrm{dl}$ ), compared with $101.2,78.0$ and $95.3 \mathrm{mg} / \mathrm{dl}$ for CO, RS and MR, respectively. Many authors reported that Zingiberofficinale rhizomes have anti-hyperlipidemia and anti-hypocholestrolemic (Suekawa et al., 1984; Young et al., 2005; Ghayur and Gilani, 2005 and Goyal and Kadnur, 2006).

The hypo-lipidemic and hypo-cholestrolemic effects of Marjoram, Rosemary and Ginger are probably due to a decrease in dietary cholesterol absorption or to an increase in bile acid synthesis and/or through its fecal losses. Peschel et al., (2007) suggested that Rosemary can inhibit lipid oxidation and scavenge superoxide radicals. Nakatani (2003), also reported that phenolic diterpenes from rosemary are particularly anti-oxidative. 
Table 3: Serummetabolitesand Testosterone concentrations of NZW rabbit bucks as affected by supplemental feeding with medicinal plants (LS-means \pm SE).

\begin{tabular}{|c|c|c|c|c|c|c|}
\hline \multirow{2}{*}{ Serum Constituent } & \multicolumn{5}{|c|}{ Treatment groups } & \multirow{2}{*}{$\pm \mathrm{SE}$} \\
\hline & $\mathrm{CO}$ & $\mathbf{R S}$ & MR & $\overline{Z R}$ & MX & \\
\hline Glucose, $\mathrm{mg} / \mathrm{dl}$ & $120.3^{\mathrm{a}}$ & $97.7^{\mathrm{ab}}$ & $108.3^{\mathrm{ab}}$ & $91.3^{\mathrm{b}}$ & $108.0^{\mathrm{ab}}$ & $\overline{7.74}$ \\
\hline Total protein, $\mathrm{g} / \mathrm{dl}$ & $6.07^{\mathrm{b}}$ & $8.12^{\mathrm{a}}$ & $7.70^{\mathrm{a}}$ & $7.25^{\mathrm{ab}}$ & $7.63^{\mathrm{a}}$ & 0.39 \\
\hline Albumin, g/dl & 3.83 & 4.23 & 3.90 & 4.03 & 4.07 & 0.31 \\
\hline Globulin, g/dl & 3.17 & 3.89 & 3.87 & 3.22 & 3.57 & 0.37 \\
\hline AL/GL ratio & 1.21 & 1.16 & 1.01 & 1.26 & 1.14 & 0.16 \\
\hline Triglyceride, mg/dl & $192.3^{\mathrm{a}}$ & $136.0^{b}$ & $136.7^{b}$ & $101.0^{\mathrm{bc}}$ & $70.3^{\mathrm{c}}$ & 13.3 \\
\hline Total cholesterol, mg/dl & $101.2^{\mathrm{a}}$ & $78.0^{\mathrm{ab}}$ & $95.3^{\mathrm{a}}$ & $60.67^{b}$ & $53.0^{b}$ & 9.91 \\
\hline Urea-N, mg/dl & 22.3 & 20.3 & 22.7 & 20.3 & 21.0 & 1.3 \\
\hline Creatinine, mg/dl & 1.01 & 0.91 & 0.99 & 0.85 & 0.76 & 0.09 \\
\hline AST, IU/dl & 28 & 28.7 & 28.7 & 31.7 & 29.7 & 3.69 \\
\hline ALT, IU/dl & 13.3 & 15.7 & 16.0 & 19.3 & 16.0 & 3.09 \\
\hline AST/ALT ratio & 2.11 & 1.84 & 1.79 & 1.65 & 1.87 & 0.48 \\
\hline Testosterone free, $\mathrm{ng} / \mathrm{ml}$ & $1.25^{\mathrm{c}}$ & $1.77^{\mathrm{bc}}$ & $1.52^{\mathrm{c}}$ & $2.48^{\mathrm{ab}}$ & $2.71^{\mathrm{a}}$ & 0.28 \\
\hline
\end{tabular}

Feeding NZW rabbit bucks on rosemary (RS), marjoram (MR), ginger $(\mathrm{ZR})$ and their mixture $(\mathrm{MX})$ did not affect serum urea-N and creatinine significantly compared with the control(Table 3). Similar results were obtained by Ibrahim (2010) feeding diets containing ginger and thyme to growing NZW rabbits, but Chiofalo et al. (2012) found in dairy ewes that rosemary (Rosmarinus officinalis) extract supplementation increased $(\mathrm{P}<0.05)$ blood concentrations of creatinine.

Means of aspartate transaminase (AST) and alanine transaminase (ALT) or AST/ALT did not differ among treatments (Table3). In contrast, Seleem et al. (2007) found that adding 3\% marjoram (Origanum majorana) to growing NZW rabbit diets increased $(\mathrm{P} \leq 0.05)$ the concentrations of AST and ALT, but the increase was still within normal range.

Serum testosterone level was higher $(\mathrm{P} \leq 0.05)$ in rabbit bucks treated with ZR and MX compared to other treatment groups. Means of RS and MR groups did not differ from that of the CO group. (Table 3). Similarly, Amr and Hamza (2006) found testosterone level was elevated in ginger supplemented rabbits and suggested that the increase may be related to its contents which have potent androgenic activity in male rat. Moreover, Seleem et al. (2007) found that serum concentration of testosterone was significantly $(\mathrm{P}<0.05)$ higher $(4.7 \mathrm{ng} / \mathrm{ml})$ in NZW rabbit bucks fed diets 
containing 3\% marjoram (Origanum majorana) compared with the control $(3.6 \mathrm{ng} / \mathrm{ml})$. Data on the effects of other medicinal plants on testosterone level are scarce.

\section{Semen characteristics:}

Semen color (Table 4) did not differ significantly ( $\mathrm{P}>.05)$ due to feeding medicinal plants. Semen density means were higher $(\mathrm{P} \leq 0.05)$ in treatment groups ZR and MX than the control. Means of RS and MR did not differ significantly from the control. Bucks of the RS, ZR and MX groups had higher $(\mathrm{P} \leq 0.05)$ mass motility score compared with the control group but MR did not differ from the control (Table 4).

Table 4.Semen color, density and mass motility(score) of NZW rabbit bucks as affected by supplementation with medicinal plants.

\begin{tabular}{|c|c|c|c|c|c|}
\hline \multirow{2}{*}{ Items } & \multicolumn{5}{|c|}{ Treatment groups } \\
\hline & $\mathrm{CO}$ & $\mathbf{R S}$ & MR & $\mathbf{Z R}$ & MX \\
\hline $\begin{array}{l}\text { Color } \\
(\text { score 1-3)* }\end{array}$ & $2.0 \pm 0.25$ & $2.0 \pm 0.25$ & $2.2 \pm 0.18$ & $2.2 \pm 0.12$ & $2.4 \pm 0.21$ \\
\hline $\begin{array}{l}\text { Density } \\
(\text { score } 0-3) * *\end{array}$ & $1.6^{\mathrm{b}} \pm 0.39$ & $1.8^{\mathrm{ab}} \pm 0.44$ & $1.8^{\mathrm{ab}} \pm 0.31$ & $2.2^{\mathrm{a}} \pm 0.18$ & $2.0^{\mathrm{a}} \pm 0.28$ \\
\hline $\begin{array}{l}\text { Mass motility } \\
\text { (score0-5)*** }\end{array}$ & $3.0^{\mathrm{c}} \pm 0.25$ & $3.4^{\mathrm{b}} \pm 0.2$ & $2.8^{\mathrm{c}} \pm 0.28$ & $3.8^{\mathrm{a}} \pm 0.11$ & $3.6^{\mathrm{ab}} \pm 0.2$ \\
\hline
\end{tabular}

The present results of semen color in NZW rabbit bucks are in agreement with those obtained by El-Sherbiny (1987) and Abd El-Ghaffar (1992). Also, Abd El-Azim and El-Kamash (2011) indicated that density and mass motility score of semen were 1.99 and 2.90 in NZW rabbits. In sheep, Mudhaffar and Saad (2012) reported that Awassi male lamb supplemented with $2.5 \%$ Ginger (Zingiber officinale) increased $(\mathrm{P}<0.05)$ mass motility of semen as compared with the control group.

Ejaculate volume of rabbit bucks in all treatment groups are presented in Table 5. Overall means of ejaculate volume were significantly higher in MR, ZR and MX groups compared with the control but RS group did not differ significantly from the control. Also, the effect of collection week on ejaculate volume was significant $(\mathrm{P}<0.001)$. It was observed that ejaculate volume was significantly $(\mathrm{P}<0.05)$ lower in the 1 st week compared to all other weeks. In contrast, Ogbuewu et al. $(2013 ; 2014$ a \& b) indicated that 
dietary inclusion of ginger (Zingiber officinale) rhizome powder at 5, 10 and $15 \mathrm{~g}$ per $\mathrm{kg}$ feed had deleterious effects on ejaculate volume of pubertal rabbit bucks.

Table 5. Means of semen characteristics of NZW rabbit bucks as affected by medicinal plants dietary treatments (LS-means \pm SE).

\begin{tabular}{|c|c|c|c|c|c|c|}
\hline \multirow[t]{2}{*}{ Items } & \multicolumn{5}{|c|}{ Treatment groups } & \multirow[b]{2}{*}{$\pm \mathrm{SE}$} \\
\hline & $\mathrm{CO}$ & $\mathbf{R S}$ & MR & $\overline{\mathbf{Z R}}$ & MX & \\
\hline Ejaculate volume $(\mathrm{ml})$ & $0.81^{\mathrm{c}}$ & $0.86^{\mathrm{c}}$ & $1.07^{\mathrm{ab}}$ & $1.01^{\mathrm{b}}$ & $1.12^{\mathrm{a}}$ & 0.05 \\
\hline $\begin{array}{l}\text { Advanced sperm motility } \\
(\%)\end{array}$ & $63.6^{\mathrm{c}}$ & $71.3^{\mathrm{b}}$ & $61.3^{\mathrm{d}}$ & $73.8^{\mathrm{a}}$ & $72.7^{\mathrm{ab}}$ & 3.6 \\
\hline Live spermatozoa (\%) & $78.9^{\mathrm{c}}$ & $83.8^{\mathrm{a}}$ & $81.4^{\mathrm{b}}$ & $82.8^{\mathrm{a}}$ & $84.0^{\mathrm{a}}$ & 2.7 \\
\hline Sperm cell conc. $\left(\mathrm{x} 10^{6} / \mathrm{ml}\right)$ & $409.1^{\mathrm{d}}$ & $473.2^{c}$ & $361.9^{\mathrm{e}}$ & $553.3^{\mathrm{a}}$ & $507.6^{\mathrm{b}}$ & 32.7 \\
\hline $\begin{array}{l}\text { Total sperm output } \\
\left(\mathrm{x} 10^{6} / \text { ejac. }\right)\end{array}$ & $330.4^{\mathrm{c}}$ & $409.5^{\mathrm{b}}$ & $396.7^{b}$ & $558.8^{\mathrm{a}}$ & $569.4^{\mathrm{a}}$ & 42.7 \\
\hline $\begin{array}{l}\text { Live normal sperm output } \\
\text { (x10\% } / \text { ejac.) }\end{array}$ & $227.1^{\mathrm{d}}$ & $311.0^{\mathrm{c}}$ & $287.8^{\mathrm{c}}$ & $417.7^{\mathrm{b}}$ & $443.7^{\mathrm{a}}$ & 39 \\
\hline
\end{tabular}

$\mathrm{a}, \mathrm{b}$....e: Means within the same row with different superscripts differ $(\mathrm{P}<0.05), \mathrm{SE}=$ standard error.

$\mathrm{CO}=$ Control; $\mathrm{RS}=$ Rosemary; $\mathrm{MR}=$ Marjoram; $\mathrm{ZR}=$ Ginger; $\mathrm{MX}=$ mixture of $\mathrm{RS}, \mathrm{MR}$ and $\mathrm{Z}$

The present results might indicate the beneficial effects of marjoram and ginger and mixture on the accessory sex glands (seminal vesicles and prostate) to produce large volume of seminal plasma and/or might be attributed to an increase in testosterone concentration in the blood (Etchu and Egbunike, 2002). The secretary functions of the accessory sex glands are very sensitive to dietary changes and the slight changes in feed chemical composition goes a long way in influencing the semen volume (Ogbuewu et al., 2013). The accessory sex glands are functionally controlled by testosterone (Hafez, 2000).

Sperm motility percentages in rabbit bucks semen of different treatment groups are presented in Table 5. Overall means of RS, ZR and MX treatments were higher $(\mathrm{P}<0.05)$ than the $\mathrm{CO}$ treatment. However, MR group had the lowest mean of all $(\mathrm{P}<0.05)$. The increase in sperm motility of $\mathrm{ZR}$ group in comparison to the control group could be due to the protective effect of ginger administration. Ginger rhizome contains a wide variety of both antoxidative (Sekiwa et al., 2000) and androgenic activity (Kamtchouing et al., 2002). The major active phenolic ingredients isolated from Z. officinale (Zingerone, Gingerdiol, Zingibrene, gingerols and shogaols) have antioxidant activity (Zancan et al., 2002; Kamtchouing et al., 2002; Jorsaraei et al., 2008). 
Table 6. Overall means of semen characteristics of NZW rabbit bucks as affected by medicinal plants dietary treatments at different weeks (LS- means \pm SE).

\begin{tabular}{|c|c|c|c|}
\hline \multirow[b]{2}{*}{$\begin{array}{c}\text { Collection } \\
\text { week }\end{array}$} & \multicolumn{3}{|c|}{ Semen characteristics } \\
\hline & $\begin{array}{c}\text { Ejaculate } \\
\text { volume }(\mathrm{ml})\end{array}$ & $\begin{array}{l}\text { Advanced sperm } \\
\text { motility }(\%)\end{array}$ & $\begin{array}{c}\text { Sperm cell } \\
\text { concentration } \\
(\mathbf{x 1 0} / \mathrm{ml})\end{array}$ \\
\hline 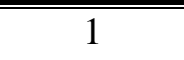 & $0.80^{\mathrm{b}}$ & $65.0^{\mathrm{b}}$ & $323.9^{\mathrm{e}}$ \\
\hline 2 & $0.99^{\mathrm{a}}$ & $66.4^{b}$ & $356.0^{\mathrm{d}}$ \\
\hline 3 & $0.99^{\mathrm{a}}$ & $67.0^{b}$ & $427.2^{c}$ \\
\hline 4 & $0.98^{\mathrm{a}}$ & $66.6^{b}$ & $474.8^{b}$ \\
\hline 5 & $0.96^{\mathrm{a}}$ & $70.6^{\mathrm{a}}$ & $490.9^{b}$ \\
\hline 6 & $0.99^{\mathrm{a}}$ & $70.8^{\mathrm{a}}$ & $508.3^{\mathrm{a}}$ \\
\hline 7 & $0.97^{\mathrm{a}}$ & $70.4^{\mathrm{a}}$ & $518.0^{\mathrm{a}}$ \\
\hline 8 & $1.04^{\mathrm{a}}$ & $69.8^{\mathrm{a}}$ & $524.2^{\mathrm{a}}$ \\
\hline 9 & $1.03^{\mathrm{a}}$ & $70.2^{\mathrm{a}}$ & $526.3^{\mathrm{a}}$ \\
\hline$\pm \mathrm{SE}$ & \pm 0.03 & \pm 0.89 & \pm 6 \\
\hline
\end{tabular}

In addition, Hamza (2006) reported that ginger have protective effects against cisplatin-induced testicular damage and oxidative stress in rats. Amrand Hamza (2006) showed that ginger has the ability to increase the activities of testicular antioxidant enzymes and restoring sperm motility of cisplatin-treated rats. While, the low sperm motility recorded in MR group could be attributed in part to the rapidity of sperm cell development in the seminiferous tubules, in the sense that spermatozoa may need a moderate but progressive development for them to have excellent motility (Ogbuewu et al., 2013).

Live sperm percentages of rabbit bucks in all treatment groups are presented in Table 5. No interaction was found between dietary treatment and week. Overall means of all treatment groups were higher $(\mathrm{P}<0.05)$ than that of the control. The MR group had the lowest mean compared to the other treated groups. The improvements in the percentage of live sperms may be attributed to the antioxidant effects of medicinal plants. Antioxidants actually brake or prevent the lytic activity within semen fluid (Rajeev et al., 2006 and Yang $e t$ al., 2006), thereby reducing lipid oxidation which lead to the deterioration of semen quality (Sekiwa et al., 2000). The increase in the percentage of dead 
spermatozoa could be attributed to acceleration of the release of immature spermatozoa in marjoram group (MR). Marjoram at this inclusion level might also inhibits the maturation of normal sperm cells by suppressing semen antioxidant systems that protect spermatozoa from oxidative stress caused by reactive oxygen species (Ogbuewu et al., 2013).

Sperm cell concentration $\left(\times 10^{6}\right)$ in semen of rabbit bucks in all treatment groups are presented in Table 5. The effect of dietary treatment on sperm cell concentration was significant. The ZR group had the highest mean followed by MX, RS, CO and MR groups. Sperm cell concentration increased significantly within weeks until wk. 6 then the increase was not significant (Table 6).These results indicated that sperm cell concentration was associated with the development of the testes and consequently spermatogenesis increased with the advancement of age.This increase could be due to increased serum testosterone level which stimulated the spermatogenic cells to undergo successful spermatogenesis, sperm maturation in the epididymes and increased the secretory activity of the accessory sex glands (Greenspan and Stawler, 1997; Gelain et al., 2005).

The interaction between dietary treatment and week for total and live normal sperm outputs were significant $(\mathrm{P}<0.01)$. Total and live normal sperm output in semen of rabbit bucks in all treatment groups at different collection weeks are presented in Tables $7 \& 8$. The ZR and MX treatments from wk. 1, 2, 4, 5,6,7, 8 and 9 had the highest mean $(\mathrm{P}<0.05)$ than the $\mathrm{CO}$.

In general, the observed improvement in all semen characteristics of rabbit bucks fed medicinal plants (Rosemary, Ginger, Marjoram and their mixture) may be attributed to their a protective function against oxidative damage of spermatogonia and spermatocytes membranes through the reduction of endogenously formed hydroperoxides of unsaturated fatty acids (Fujii et al., 1984).

Sperm abnormality percentages in semen of rabbit bucks of different treatment groups at different collection weeks are presented in Table 9. The interaction of experimental diet $\chi$ collection week on sperm abnormality was significant. The MX treatment from wk. 4, 7, 8 and 9 had the lowest mean $(\mathrm{P}<0.05)$ than the CO treatment. No differences were found between the other medicinal plants treated groups and the control (Table9). Seleem et al., (2007) reported that feeding NZW rabbit bucks on diets containing 3\% marjoram (Origanummajorana) decreased $(\mathrm{P} \leq 0.05)$ their abnormal sperm cells from $16 \%$ in the control diet to $12.7 \%$ in marjoram diet. In general, the range of abnormal sperms in this study during the collection period ranged from 3.85 to $12.95 \%$ for all groups, which are within the normal range of abnormal sperm (7.513.17) as reported by many authors with different breeds. 
Table 7. Total sperm output (x $10^{6} \%$ jaculate) in semen of NZW rabbit bucks in treatment groups at different weeks (LS-means $\pm \mathrm{SE}$ ).

\begin{tabular}{cllllll}
\hline \hline $\begin{array}{c}\text { Collection } \\
\text { week }\end{array}$ & \multicolumn{5}{c}{ Treatment groups } & \\
\cline { 2 - 6 } & CO & RS & MR & ZR & MX & \pm SE \\
\hline \hline 1 & $178.9^{\mathrm{b}}$ & $255.1^{\mathrm{ab}}$ & $194.4^{\mathrm{b}}$ & $347.4^{\mathrm{a}}$ & $345.4^{\mathrm{a}}$ & 31.2 \\
\hline 2 & $309.5^{\mathrm{bc}}$ & $350^{\mathrm{abc}}$ & $245.9^{\mathrm{c}}$ & $425.9^{\mathrm{a}}$ & $459.3^{\mathrm{a}}$ & 44.8 \\
\hline 3 & 386.3 & 465.3 & 312.5 & 474.5 & 472.7 & 55.3 \\
\hline 4 & $354.1^{\mathrm{c}}$ & $409.5^{\mathrm{bc}}$ & $376.6^{\mathrm{c}}$ & $616.8^{\mathrm{a}}$ & $603.9^{\mathrm{ab}}$ & 66.5 \\
\hline 5 & $338.4^{\mathrm{c}}$ & $399.3^{\mathrm{bc}}$ & $461.7^{\mathrm{abc}}$ & $564.9^{\mathrm{ab}}$ & $593.2^{\mathrm{a}}$ & 58.3 \\
\hline 6 & $321.4^{\mathrm{c}}$ & $428.7^{\mathrm{bc}}$ & $520.8^{\mathrm{ab}}$ & $625.1^{\mathrm{a}}$ & $625.9^{\mathrm{a}}$ & 53.9 \\
\hline 7 & $342.9^{\mathrm{c}}$ & $432.7^{\mathrm{bc}}$ & $473.0^{\mathrm{abc}}$ & $579.7^{\mathrm{ab}}$ & $665.7^{\mathrm{a}}$ & 68.5 \\
\hline 8 & $362.1^{\mathrm{b}}$ & $475.1^{\mathrm{b}}$ & $497.9^{\mathrm{b}}$ & $696.1^{\mathrm{a}}$ & $701.9^{\mathrm{a}}$ & 52.1 \\
\hline 9 & $379.9^{\mathrm{b}}$ & $469.9^{\mathrm{b}}$ & $487.3^{\mathrm{b}}$ & $699.1^{\mathrm{a}}$ & $656.3^{\mathrm{a}}$ & 42.7 \\
\hline \hline
\end{tabular}

$\overline{\mathrm{a}, \mathrm{b} \text { and } \mathrm{c}}$ : Means within the same row with different superscripts differ $(\mathrm{P}<0.05), \mathrm{SE}=$ standard error.

$\mathrm{CO}=$ Control; $\mathrm{RS}=$ Rosemary; $\mathrm{MR}=$ Marjoram; $\mathrm{ZR}=$ Ginger; $\mathrm{MX}=$ mixture of $\mathrm{RS}, \mathrm{MR}$ and $\mathrm{ZR}$.

Table 8.Live normal sperm output (x $10^{6} \%$ jaculate) in semen of NZW rabbit bucks in treatment groups at different weeks (LS-means \pm SE).

\begin{tabular}{|c|c|c|c|c|c|c|}
\hline \multirow{2}{*}{$\begin{array}{c}\text { Collection } \\
\text { week }\end{array}$} & \multicolumn{5}{|c|}{ Treatment groups } & \multirow[b]{2}{*}{$\pm \mathrm{SE}$} \\
\hline & $\mathrm{CO}$ & $\mathbf{R S}$ & MR & $\mathbf{Z R}$ & MX & \\
\hline$\overline{1}$ & $1118.1^{\mathrm{b}}$ & $189.8^{\mathrm{ab}}$ & $134.3^{\mathrm{b}}$ & $254.1^{\mathrm{a}}$ & $261.7^{\mathrm{a}}$ & $\overline{27.4}$ \\
\hline 2 & $195.0^{b}$ & $260.7^{\mathrm{ab}}$ & $172.2^{\mathrm{b}}$ & $318.3^{\mathrm{a}}$ & $335.5^{\mathrm{a}}$ & 34.6 \\
\hline 3 & 261.4 & 344.6 & 224.3 & 332.8 & 352.2 & 46.5 \\
\hline 4 & $232.7^{b}$ & $328.5^{\mathrm{ab}}$ & $259.7^{b}$ & $474.2^{\mathrm{a}}$ & $485.3^{\mathrm{a}}$ & 53.3 \\
\hline 5 & $246.2^{b}$ & $305.4^{\mathrm{ab}}$ & $330.3^{\mathrm{ab}}$ & $413.8^{\mathrm{a}}$ & $470.3^{\mathrm{a}}$ & $\overline{52.6}$ \\
\hline 6 & $233.1^{b}$ & $320.6^{\mathrm{ab}}$ & $387.2^{\mathrm{ab}}$ & $475.7^{\mathrm{a}}$ & $480.6^{\mathrm{a}}$ & 50.6 \\
\hline 7 & $236.5^{\mathrm{c}}$ & $321.1^{b c}$ & $338.9^{\mathrm{bc}}$ & $436.6^{\mathrm{ab}}$ & $523.3^{\mathrm{a}}$ & 56.4 \\
\hline 8 & $240.0^{c}$ & $369.3^{\mathrm{bc}}$ & $374.9^{\mathrm{bc}}$ & $524.9^{\mathrm{ab}}$ & $554.8^{\mathrm{a}}$ & 50.9 \\
\hline 9 & $280.8^{b}$ & $358.9^{b}$ & $368.4^{b}$ & $528.7^{\mathrm{a}}$ & $526.8^{\mathrm{a}}$ & 40.8 \\
\hline $\begin{array}{c}\text { Overall } \\
\text { Mean } \pm \text { SE } \\
\end{array}$ & $\begin{array}{l}227.1^{\mathrm{d}} \\
\pm 39 \\
\end{array}$ & $\begin{array}{l}311.0^{c} \\
\pm 39\end{array}$ & $\begin{array}{l}287.8^{c} \\
\pm 39 \\
\end{array}$ & $\begin{array}{l}417.7^{\mathrm{b}} \\
\pm 39\end{array}$ & $\begin{array}{l}443.7^{a} \\
\pm 39\end{array}$ & \\
\hline
\end{tabular}

...d: Means within the same row or column with different superscripts differ $(\mathrm{P}<0.05), \mathrm{SE}=$ standard error.

$\mathrm{CO}=$ Control; $\mathrm{RS}=$ Rosemary; $\mathrm{MR}=$ Marjoram; $\mathrm{ZR}=$ Ginger; $\mathrm{MX}=$ mixture of $\mathrm{RS}, \mathrm{MR}$ and ZR. 
Table 9. Abnormal spermatozoa (\%) in semen of NZW rabbit bucks in treatment groups at different weeks (LS-means \pm SE).

\begin{tabular}{ccccccc}
\hline \hline \multirow{2}{*}{ Collection week } & \multicolumn{5}{c}{ Treatment groups } & \multirow{2}{*}{ \pm SE } \\
\cline { 2 - 5 } & $\mathbf{C O}$ & $\mathbf{R S}$ & $\mathbf{M R}$ & $\mathbf{Z R}$ & $\mathbf{M X}$ & 1.5 \\
\hline \hline 1 & 10.8 & 8.2 & 12.6 & 10.2 & 8.0 & 1.5 \\
\hline 2 & 11.0 & 9.6 & 10.0 & 8.8 & 9.4 & 1.3 \\
\hline 3 & 9.0 & 9.6 & 9.2 & 10.6 & 8.8 & 1.3 \\
\hline 4 & $9.8^{\mathrm{ab}}$ & $6.4^{\mathrm{bc}}$ & $10.8^{\mathrm{a}}$ & $7.8^{\mathrm{abc}}$ & $4.2^{\mathrm{c}}$ & 1.3 \\
\hline 5 & 11.0 & 8.2 & 9.8 & 8.4 & 7.0 & 1.8 \\
\hline 6 & 9.2 & 10.0 & 9.0 & 8.0 & 6.4 & 1.1 \\
\hline 7 & $10.0^{\mathrm{a}}$ & $7.2^{\mathrm{ab}}$ & $10.0^{\mathrm{a}}$ & $9.0^{\mathrm{a}}$ & $5.2^{\mathrm{b}}$ & 1.0 \\
\hline 8 & $11.0^{\mathrm{a}}$ & $8.0^{\mathrm{ab}}$ & $8.2^{\mathrm{ab}}$ & $8.8^{\mathrm{ab}}$ & $6.0^{\mathrm{b}}$ & 1.4 \\
\hline 9 & $9.0^{\mathrm{a}}$ & $7.0^{\mathrm{ab}}$ & $9.0^{\mathrm{a}}$ & $7.2^{\mathrm{ab}}$ & $5.0^{\mathrm{b}}$ & 1.0 \\
\hline \hline
\end{tabular}

a, b and $\mathrm{c}$ : Means within the same row with different superscripts differ $(\mathrm{P}<0.05), \mathrm{SE}=$ standard error.

$\mathrm{CO}=$ Control; RS=Rosemary; MR= Marjoram; $\mathrm{ZR}=$ Ginger; $\mathrm{MX}=$ mixture of RS, MRand ZR .

\section{Histological Examination:}

In this work, the internal organs; testes, liver, and kidney were histologically examined to study the effect of using medicinal plants in the diet of NZW rabbit bucks on the histological structure of the studied organs. Testicular sections of control group $(\mathrm{CO})$ revealed that convoluted seminiferous tubules were lined with sertoli cells and spermatogenic cells at different stages of development (Figure1, Plate a \& b). All the experimental groups were similar to the control group except that ZR group (Figure 1, Plate 4b) showed plentiful and more apparent elongated spermatids. In addition to in MX group (Figure 1, Plate 5a); leydig cells were more developed in comparison to other experimental groups. Bordbar et al., (2013) reported that the increase of the testosterone level might have resulted from the Leydig cells which are found in the interstitial tissue and secret testosterone. It could be explained on the basis that enhancement of volume or number of Leydig cells resulted in elevation of the testosterone 
level. It has been established that ginger has antioxidant properties which can be contributed to its protective components such as zingerone, gingerdiole, zingirbrene, gingerls and shagaols (Kamtchouing et al., 2002; Shalaby and Hamowieh, 2010; Memudu et al., 2012). These compounds prevent DNA damages and destruction of genome induced by $\mathrm{H}_{2} \mathrm{O}_{2}$ (Zancan et al., 2002 and Khaki et al., 2009). It would be expected that ginger cause an increase in the spermatogenesis number and seminiferous tubules volume by preventing apoptosis in the spermatogenesis process.

Many studies showed that ginger was scavenging free radical by its potent antioxidant properties. Amin and Hamza (2005) demonstrated that Zingeber officinal increased the activities of testicular antioxidant enzymes, superoxide dismutase, glutathione and catalase and reduced level of malondialdhyde.

Histological examination of the liver sections of control group (CO) revealed normal histological structure (Figure 2, Plate 1a\&b); anastomosing laminae of hepatocytes were separated by blood sinusoids. Kupffer cells were observed in the blood sinusoids (Fig.2, Plate 1b).The current finding revealed that hepatic blood sinusoids were dilated in the RS group, this was in accordance with Monira et al. (2012) who stated that animals fedrosemary extract exhibited a normal hepatic architecture with slight dilatation between hepatic cords. Although this finding was recorded in animals subjected to high doses $(500 \mathrm{mg} / \mathrm{kg})$ of Zingerber officinale (Amabe, 2014).

Our investigation emphasized that there was an increase in the number of mononuclear phagocytic cells in the MR group (Figure 2, Plate 3a) and ZR group (Figure 2, Plate 4a); especially in the portal traids and among the hepatic lobules. In addition to, ZR group (Figure 2, Plate 4b) showed enlarged Kupffer cells. Dilated blood sinusoids were distinguished in the RS group (Figure 2, Plate 2b) and MR group (Figure 2, Plate). This was in agreement with Nusaibah et al. (2013) who reported that aggregation of mononuclear cells mainly macrophage and lymphocyte in liver parenchyma was observed in liver section of mice treated with Ginger (Zingeber officinalle). Du et al. (2010) recorded that Zingeber officinale can maintain the normal immune function of immune system because it increases the higher titer of antibody such as IgG, IgA and IgM.

The present study had revealed an increase in the size and number of bile ducts of the experimental groups; the significant changes were apparent in the RS group (Figure 2, Plate 2 a \& b) and to a lesser extent in the MR group (Figure 2, Plate 3a) and MX group (Figure 2, Plate 5a). This was in agreement with Fernando et al. (2008) who attributed the bile duct 
hyperplasia of animals subjected to RS, probably due to the extremely high level of RES uptake relative to body weight. Liver sections of animals fed rosemary leaves showed dilated and congested portal vein (Yasamin et al., 2013); who suggested that the physiological activity of the rosemary (Rosmarinus officinalis) can be attributed to the volatile oil. Alpha-pinene, camphene, verbenone, camphor, cineole, bronyl-acetate and borneol are all active compounds of the rosemary (Rosmarinus officinalis) and determine the biological Properties of the essential oil and can act in synergic manner or regulate one another.

Examined sections of kidney show normal renal corpuscles surrounded by renal tubules (Figure 3, Plate 1a\&b). There was no magnificent changes in the kidney sections of experimental groups (Figure 3, Plates 2, 3, 4 \&5) except that few congested blood vessels were observed in the MR group (Figure 3, Plate 3b) and ZR group (Figure 3, Plate 4b) and Mix group (Figure 3, Plate 5a). Monira et al. (2012), Histological study of the kidneys of the control rats revealed normal glomerulus surrounded by the Bowman's capsule, proximal and distal convoluted tubules without any inflammatory changes. Rosemary has no histopathological effects in renal tissues of rats. Rosemary is one of the plants rich in different phytochemical derivatives such as triterpenes, flavonoids or polyphenols. Its extracts are able to donate electrons to reactive radicals, converting them to more stable and non-reactive species, therefore preventing them from reaching biomolecules, such as lipoproteins, polyunsaturated fatty acids, DNA, amino acids, proteins and sugars, in susceptible biological systems. It was concluded that RS extracts have a high scavenging capacity of different types of reactive oxygen species which is one of the main mechanisms of the antioxidant action exhibited by phenolic phytochemicals Mohammad et al., (2013) stated that long term treatment of diabetic rats with Origanum majorana can partially protect the renal tissue via attenuation of oxidative stress and glomerular expansion. Ibrahim et al. (2005) concluded that Origanum majorana plays an important role in ameliorating liver and kidney functions and genotoxicity induced by lead toxicity.

Conclusively, the medicinal plants, Rosemary (Rosmarinus officinalis), Marjoram (Origanum majorana), Ginger root (Zingiber officinale) and their mixture could be added to NZW rabbit diets within the limits recorded in this study to improve semen characteristics and reproductive performance of NZW rabbit bucks without any detrimental effects on their health. 
SHETAEWI et al.
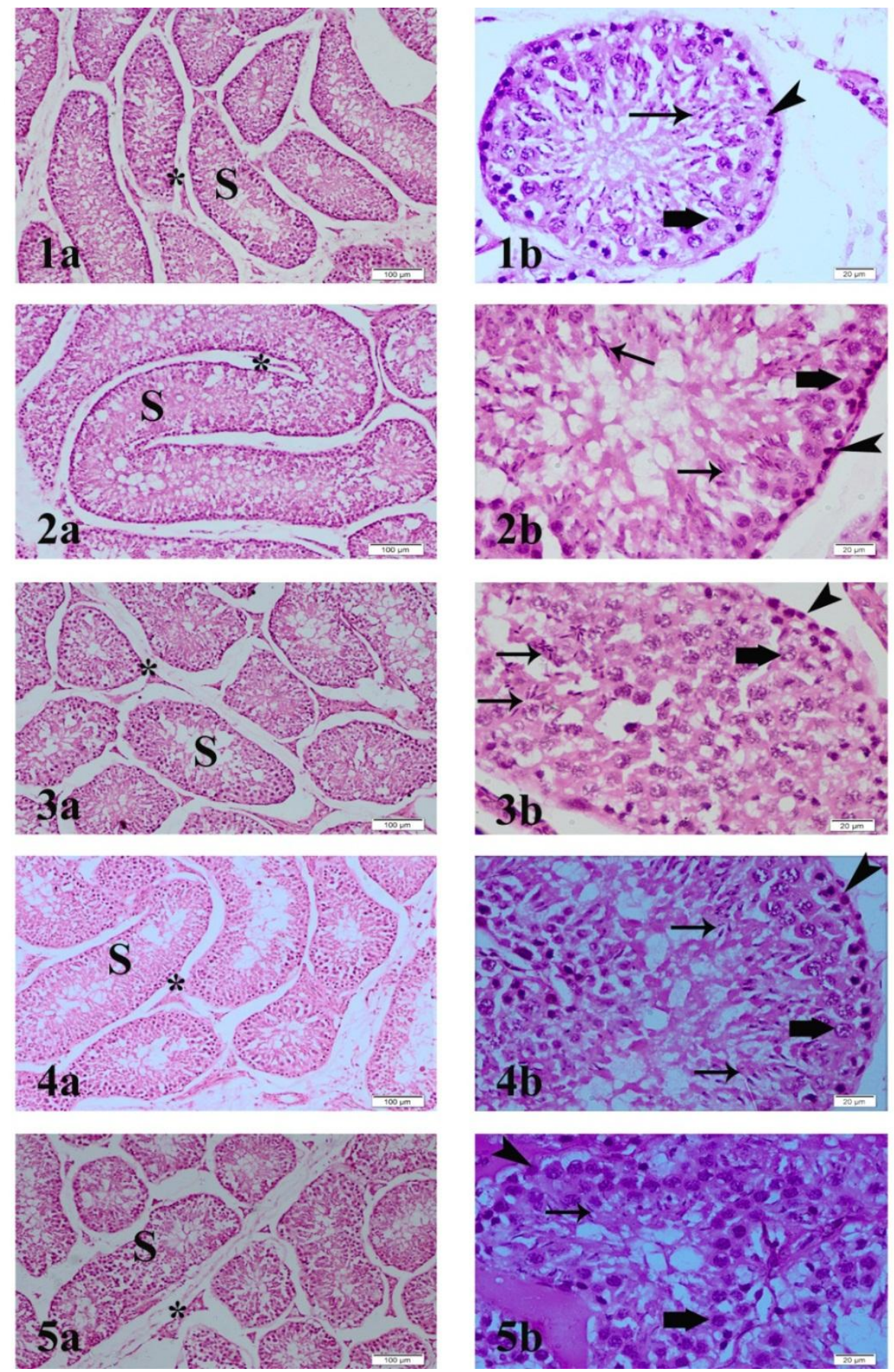

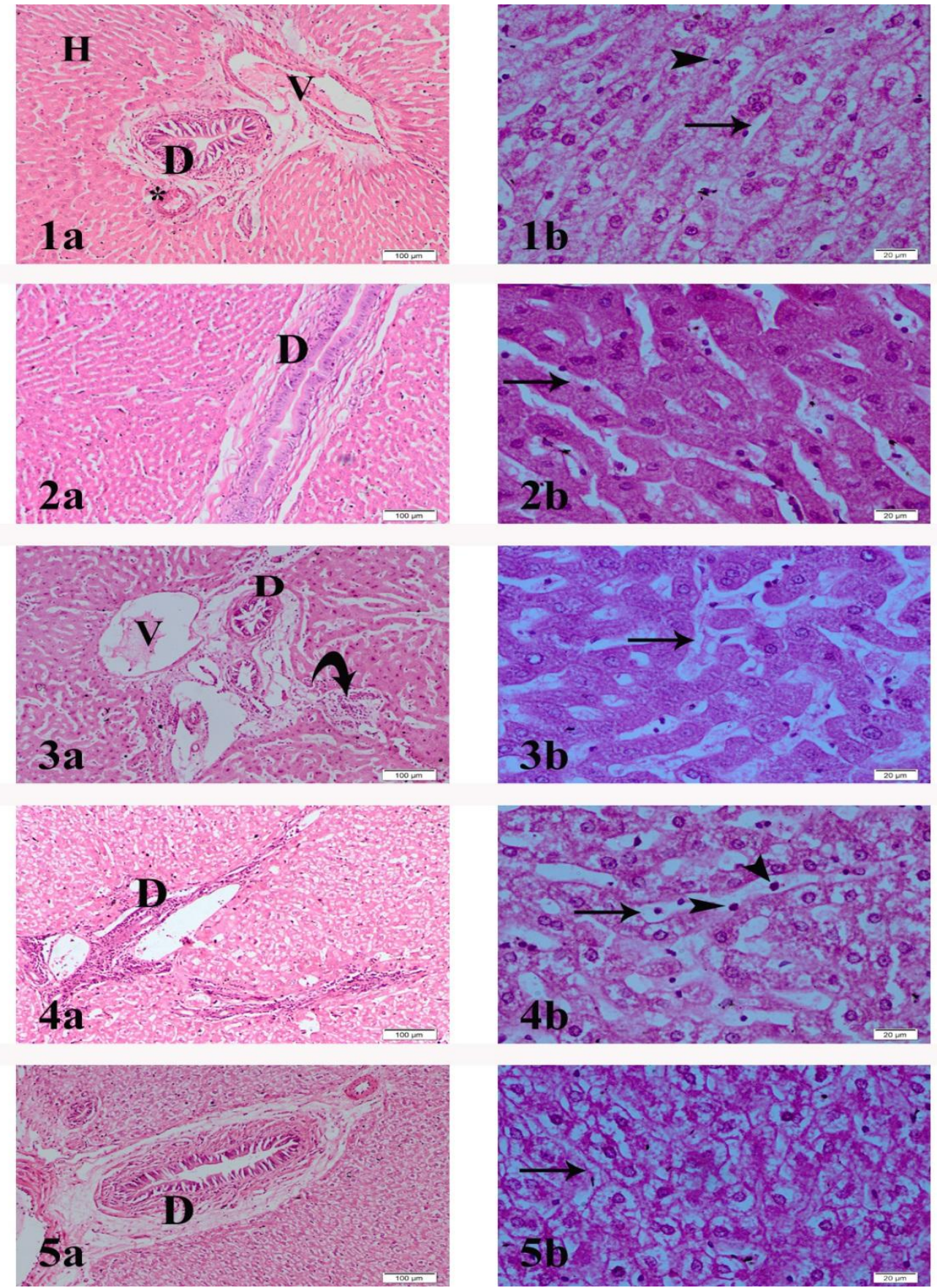
SHETAEWI et al.
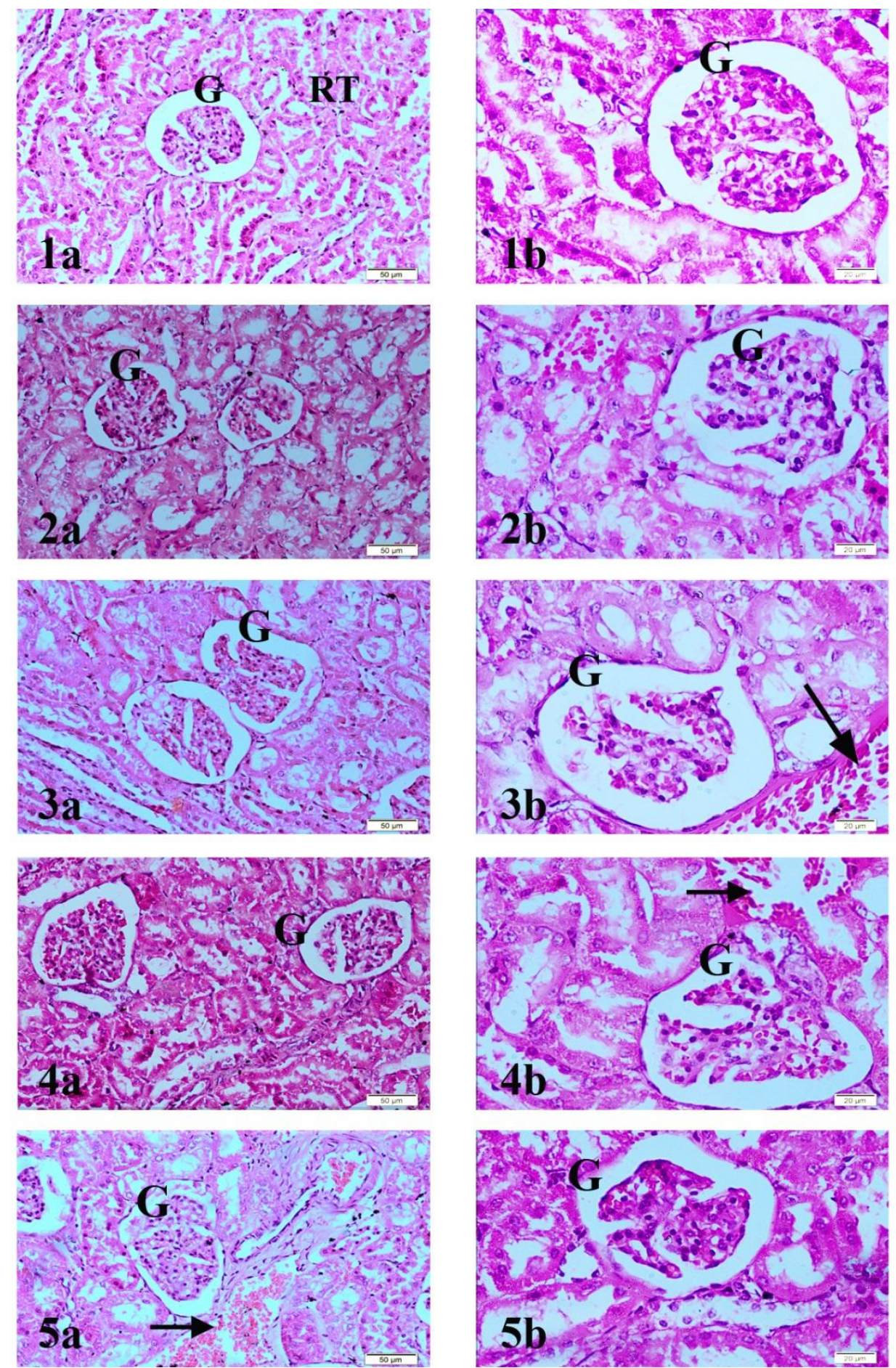


\section{REFERENCES}

A.O.A.C. (1995).Association of Official Analytical Chemists.Official Methods of Analysis. " $17^{\text {th }}$ Ed. Published by the A.O.A.C. Washington, DC, USA.

Abaza, I. M. and El-Said, H. (2005).Effect of using yucca schidigera as feed additive on performance of growing rabbits.Proceeding $4^{\text {th }}$ Int. Conf. Rabbit Production Hot Climates, 24-27 Febr., Sharm El-Sheik, Egypt, 259-266.

Abd El-Azim, A. and El-kamash, E. M. (2011).Evaluation of semen quality and its relation to mating system for some breeds of rabbits under environmental conditions in the middle of Egypt. Egypt. Poult. Sci. 31(II): 467-480.

Abd-El-Ghaffar, A. E. (1992). Some studies on the artificial insemination in rabbits. Ph.D. Thesis, Fac. Vet. Med., ZagazigUniv. (Benha), Egypt.

Abdel-Malak, N. Y.; Abdel-Malak, M. S.; El-Gendi, G. M. and Naguib, E. F. (1995).Effect of feeding different levels of herbal feed additives on broiler performance in relation to some metabolic functions. Egypt. Poult. Sci., 15: 111-139

Abraham, G. E. (1977). Handbook of Radioimmunoassay. Edition. Marcal. Dekker.

Al-Beitawi, N. A.; El-Ghousein, S. S. and Athamneh, M. Z. (2010). Effect of adding crushed Pimpinellaanisum, Nigella sativa seeds and Thymus vulgaris mixture to antibiotics-free rations of vaccinated and non-vaccinated male broilers on growth performance, antibody titer and haematological profile. Ital. J. Anim. Sci. , 9: 222-228.

Amabe O. A. (2014). Studies of ethanolic extract of ginger (Zingiber officinale) on the histology of the liver using adult male rats. Int. J. Biol. Sci. Applic., 1(3): 84-89.

Amakye-Anim, J. T.; Lin, L.; Hestree, P. Y.; Thiagarajan, D.; Watkins, B. A. and Wc, C. C. (2000). Ascorbic acid supplementation improved antibody response to infectious bursal disease vaccination in chickens. Poultry Sci., 79: 680-688.

Amin, A. and Hamza, A. A. (2005). Hepatoprotective effects of Hibiscus, Rosmarinusand Salvia on azathioprine-induced toxicity in rats. Life Sci. , 77: 266-278.

Amr, A. and Hamza, A. E. (2006). Effects of Roselle and Ginger on Cisplatin induced reproductive toxicity in rats. Asian J. Androl., (8): 607-612. 
Bakirel, T.; Bakirel, U.; Keles, O. U.; Ulgen, S. G. and Yardibi, H. (2008). In vivo assessment of antidiabetic and antioxidant activities of rosemary (Rosmarinus officinalis) in alloxan-diabetic rabbits. $J$. Ethnopharmacol., 116: 64-73.

Bancroft, J. D. and Stevens, G. G. (1990). Theory And Practice Of Histological Techniques. $2^{\text {nd }}$ Ed. Churchill Livingstone, London.

Blom, E. (1950). A one-minute live-dead sperm stain by means of osinnigrosin. J. Fertil. Steril., 1: 176-183.

Bordbar, H.; Esmaeilpour, T.; Dehghani, F. and Panjehshahin, M. (2013). Stereological study of the effect of gingers alcoholic extract on the testis in busulfan-induced infertility in rats. Iran J. Reprod. Med., 11(6): 467-472.

Cheeke, P. R. (1987). Rabbit Feeding And Nutrition. Academic Press Inc. New York.

Chiofalo, V.; Liotta, L.; Fiumano, R.; Benedetta, E. R. and Chiofalo, B. (2012). Influence of dietary supplementation of Rosmarinusofficinalis L. on performances of dairy ewes organically managed. Small Ruminant Res., 104: 122-128.

Deutsche Veterina ermedizinische Gesellschaft (1976). Arbeitswertefuer die tieraerztliche praxis, Beilagezu: tieraerztl. Prax., 4(4): 83-102.

Du, X.; Pan, H.; Zhang, C.; Zhang, H.; Liu, H.; Chen, Z. and Zeng, X. (2010). Zingiber officinale extract modulates g-rays-induced immunosuppression in mice. J. Med. Plants Res., 4(16):1647-1655.

El- Khashab, M. A.; Semaida, A. I.; Abdel-Rahman, A. R. and Ahmed, A. H. (2011). Physiological and Reproductive Responses to heat stress amelioration in ossimi ewes under hot summer conditions in Egypt. $J$. Basic Appl. Physiol., 10 (1): 57-76.

El-Sherbiny, A. M. (1987). Seasonal variations in seminal characteristics of rabbits. M.Sc.Thesis, Fac. Agric., Ain Shams Univ., Cairo, Egypt.

Etchu, K. A. and Egbunike, G. N. (2002). Effect of processed sweet potato on the performance of broiler birds in the humid tropics during the rainy season. Trop. Anim. Prod. Invest., 5: 67-78.

Fernando, A.; Herman, A.; Sue, B.; Laurence, C.; Riccardo, C.; Wolfgang, D.; Karl-Heinz, E.; Natalie, G.; David, G.; Sandro, G.; Rainer, G.; John, C. L.; Catherine, L.; Jean-Charles, L. F.; Xavier, M.; Wim, M.; Maria, R. M.; Iona, P.; Ivonne, R.; Paul, T. and Fidel, T. (2008). Use of rosemary extracts as a food additive. The EFSA J., 721: 1-29. 
Fujii, S.; Dale, G. L. and Beutler, E. (1984).Glutathione dependent protection against oxidative damage of the human red cell membrane. Blood, 63 (5): 1096-1101.

Gelain, D. P.; Casali, E. A. and Dal-Pizzol, F. (2005). Effect of follicle stimulating hormone and vitamin A upon purinergic secretion by rat sertoli cells. Molecular Cell Biochemistry, 278: 185-195.

Ghayur, M. N. and Gilani, A. H. (2005). Ginger lowers blood pressurethrough blockade of voltage-dependent calcium channels. J. CardiovascPharmacol., 45: 74-80.

Ghlissi, Z.; Hamden, K.; Saoudi, M.; Sahnoun, Z. K.; Zeghal, M.; ElFeki, A. and Hakim, A. (2012). Effect of Nigella sativa seeds on reproductive system of male diabetic rats. Afr. J. Pharm. Pharmacol., 6(20): 1444-1450.

Gill, J. (1978). Design and analysis of experiments in the Animal and Medical Sciences. Iowa state Univ. Press, Ames.

Goyal, R. K. and Kadnur, S. V. (2006). Beneficial effects of Zingiberofficinale on goldthioglucose-induced obesity. Fitoterapia, 77: 160-163.

Greenspan, F. S. and Stawler, G. J. (1997). Basic And Clinical Endocrinology. New York: McGraw Hill.

Hafez, D. A. (2010). Effect of extracts of ginger roots and cinnamon bark on fertility of male diabetic rats. J. Anim. Sci., 6: 940-947.

Hafez, E. S. (2000). Reproductive behavior in: Reproduction in Farm Animals. Ed. By E.S.E. Hafez, pp.273-276.Lea and Febiger, Philadelphia, USA.

Haider, A. M, Semaida, A. I. and El-Khashb, M.A. (2010). Amelioration of heat stress with chromium in Egyptian buffalo heifers exposed to solar radiation. $6^{\text {th }}$ inter. Conf. Sustain. Agric. Develop. Fac. Agric., Fayoum Univ., pp. 27-29.

Hamza, A. A. (2006). Effects of Roselle and Ginger on cisplatin- induced reproductive toxicity in rats. Asian J. Androl., 8: 607-612

Harper, H. A.; Rodwell, V. W. and Mayer, P. A. (1977). Review of Physiological Chemistry, $6^{\text {th }}$ (Eds.). Lange Medical Publication, California.

Henry, R. J. and Cannon, D. C. (1974). Clinical Chemistry - Principles And Techniques, $2^{\text {nd }}$ Ed.

Ibrahim, M. E.; Abeer, F. E. and Osama, M. S. (2005). Protective Effect of Volatile Oil, Alcoholic and Aqueous Extracts of Origanum majorana on Lead Acetate Toxicity in Mice. Basic \& Clinical Pharmacology and Toxicology, 97: 238-243. 
Ibrahim, M. M. (2010). Effect of some untraditional diets on growth, reproduction and carcass characteristics of rabbits in north Sinai. M. Sc. Thesis, Fac. Environ. Agric. Sci., Suz Canal Univ., Egypt, 112pp.

Jorsaraei, S. G.; Yousefnia, Y. R.; Zainalzadeh, M.; Moghadamnia, A. A.; Beiky, A. A. and Damavandi, M. R. (2008). The effects of methanolic extracts of ginger (Zingiber officinale) on human sperm parameters; an in vitro study. Pak. J. Biol. Sci., 11: 1723-1727.

Kamtchouing, P.; Fandio, G. Y. M.; Dimo, T. and Jatsa, H. B. (2002). Evaluation of androgenic activity of Zingiber officinale and pentadipl and rabrazzeana in male rats. Asian J. Androl., 4:299-301.

Khaki, A.; Fatemeh, F.; Mohammad, N.; Amir, A. K.; Chelar, C. O.; Marefat, N. and Mohammad, H. (2009). The effects of ginger on spermatogenesis and sperm parameters. Iranian J. Reprod. Med., 7(1): 7-12.

Kirsch, R., L. Frith, E. Black, and R. Hoffenberg. (1968). Regulation of albumin synthesis and catabolism by alteration of dietary protein. Nature, 217:578-579

Loeb, W. F. and Quimby, F. W. (1989). The clinical Chemistry of Laboratory Animals, Pergamon, New York, Appendix.

Mascolo, N.; Jain, R.; Jain, S. C. and Capasso, F. (1989). Ethnopharmacologic investigation of ginger (Zingiber officinale). J. Ethnopharmacol, 27: 129-140.

Melrose, D. R. and Loing J. A. (1970). The characteristics of normal semen.Chap. 4, Fertility and infertility in the Domestic Animals. Ed. by J. A. Laing Bailliere Tindall and Gassell, London.

Memudu, A. E.; Akinrinade, I. D.; Ogundele, O. M. and Duru, F. (2012). Investigation of the androgenic activity of ginger (Zingiber officinale) on the histology of the testis of adult sparaguedawley rats. J. Medicine and Medical Sci., 3(11): 697-702.

Mericili, A. H. (1990). The lipophilic compounds of a Turkish Matricaria chamomilla variety with no chamazulene in the volatile oil. Int. J. of Rlude Drug Res., 28, 2: 145.

Mohammad, H. G. M.; Iman, A.; Mehrdad, R. and Mohammad, M. (2013). The Effects of Origanum majorana on Oxidative Stress and Histopathology of Renal Tissue among Streptozotocin-Induced Diabetic Rats. Thrita J. Medical Sci., 2(3): 29-34.

Monira A. A.; Nermin, M. E. and Hamdy, T. (2012). The Protective Role of Rosemary (Rosmarinusofficinalis) in Lead Acetate InducedToxicity in Rats. J. Applied Sci. Res., 8(6): 3071-3082. 
Mudhaffar, N. R. and Saad, Th. J. (2012).Effect of using Zingiberofficinalle and vitamin $\mathrm{E}$ on some reproductive traits of Awassi male lamb. The $11^{\text {th }}$ Scientific Conf., College of Vet. Med. Baghdad Univ., Iraq, 4-5 April, 134-141.

Nakatani, N. (2003). Biologically functional constituents of spices and herbs. J. Japanese Soc. Nutr. Food Sci., 56(6): 389-395.

NRC (1977). National Research Council. Nutrient Requirements of Rabbits. Washington, DC. USA.

Nusaibah, A.; Marwa, H. K.; Silva, A. Y. and Noor, N. B. (2013). Histological Effects of Excessive Consumption of Zingeber officinale on Liver and Spleen of the Mice. Iraq J. Al-Nahrain Uni., 16(2): 151156.

Ogbuewu I. P.; Etuk, I. F.; Odoemelam, V. U.; Okoli, I. C. and Iloeje, M. U. (2014b).Semen quality characteristics of post-pubertal rabbit bucks fed ginger rhizome meal based diets. Trop. Anim. Prod. Invest., 17(1): 32-35.

Ogbuewu, I. P.; Jiwuba, P. C.; Ezeokeke, C. T.; Uchegbu, M.C.; Okoli, I. C. and Iloeje, M. U. (2014a). Evaluation of phytochemical and nutritional composition of ginger rhizome powder. Int. J. Agric. and Rural Dev., 17: 1663-1670.

Ogbuewu, I. P.; Okoli, I. C. and Iloeje, M. U. (2013).The detrimental effect of dietary ginger rhizome powder supplementation on reproductive performance of pubertal rabbit bucks. Int. J. Innovation and Applied Studies, 4: 129-132.

Peschel, W.; Dieckmann, W.; Sonnenschein, M. and Plescher, A. (2007). High antioxidant potential of pressing residues from evening primrose in comparison to other oilseed cakes and plant antioxidants. Indust. Crops Prod., 25(1): 44.

Rajeev, K.; Gagan, K. and Narmada, G. (2006). Drug Therapy for Idiopathic Male Infertility: Rationale versus Evidence. J. Urol., 176: 1307-1312.

Reitman, S. and Franke, S. (1957). Anim. J. Clinical pathology. 28: 56-63.

SAS Institute Inc., (2004). SAS procedures Guide for personal Computers, Statistical Analysis System Institute, Inc., Cary, N.C.

Sekiwa, Y.; Kubota, K. and Kobayashi, A. (2000). Isolation of novel glycosides from ginger and their antioxidative activity. J. Agric. Food Chem., 8: 373-379. 
Seleem, T. S.T.; Ibrahim, H.; Ali, A. M.; Abd-Elmotaal, A. M. and Zeidan, A. E. B. (2007). Rabbit performance as affected by Origanummajorana in diets. $5^{\text {th }}$ Int. Conf. Rabbit Production in Hot Climates, 8-10 Oct., Hurghada, Egypt, 495-508.

Shalaby, M. A. and Hamowieh, A. R. (2010).Safety and efficacy of Zingiberofficinale roots on fertility of male diabetic rats. Food and Chemical Toxicology, 48: 2920-2924.

Shetaewi, M. M. (1998). Efficiency of dietary high levels of antioxidant vitamins $\mathrm{C}$ and $\mathrm{E}$ for rabbits subjected to crowding stress. Egypt. J. Rabbit Sci., 8 (2), 95-112.

Shetaewi, M. M. and T. T. Ross. (1991). Effects of concentrate supplementation and lasalocid on serum chemistry and hormone profiles in Rambouillet ewes. Small Ruminant Research, 4:365-377.

Smith, J. T. and Mayer, D. T. (1955).Evaluation of sperm concentration by the hemocytometer method. Fertil. Steril., 6: 271-275.

Steel, R. G. D. and Torrie, J. H. (1980). Principles And Procedures Of Statistics: A Biometrical Approach ( $2^{\text {nd }}$ Ed.). McGraw-Hill Book Co., New York.

Suekawa, M.; Ishige, A.; Yuasa, K.; Sudo, K.; Aburada, M. and Hosoya, E. (1984). Pharmacological studies on ginger. I. Pharmacological actions of pungent constituents, [6]-gingerol and [6]shogaol. J. Pharmacobiodyn, 7: 836-848.

Sykes, A. R. and A. C. Field. (1973). Effects of dietary deficiencies of energy, protein and calcium on the pregnant ewe. IV. Serum total protein, albumin, globulin, transferrin and plasma urea levels. J. of Agric. Sci. (Camb.), 80:29-36

Tipu, M. A.; Akhtar, M. S.; Anjum, M. I.; and Raja, M. I. (2006). New dimension of medicinal plants as animal feed. Pakistan Vet. J., 26(3): 144-148.

Woolford, S. T.; Schoroer, R. A.; Gohs, F. X.; Gallo, P. P.; Brodeck, M. and Falk, H. B. (1986). Reference rang data based for serum chemistry and hematology values in laboratory animals. J. Toxicol. Environ. Health, 18: 161.

Yang, H. S.; Han, D. K.; Kim, J. R. and Sim, J. C. (2006). Effects of alphtocopherol on cadmium-induced toxicity in rat testis and spermatogenesis. J. Korean Med. Sci., 21: 445-451.

Yasamin, T. Q.; Khaleel, I. R.; Ibtihal, I. M. and Mahera, N. A. (2013). Histological study for the biological effect of Rosemary Rosmarinusofficinalis essential oil on liver and kidney tissues. $J$. Biotech. Res. Center, 7(1): 48. 
Young, H. V.; Luo, Y. L.; Cheng, H. Y.; Hsieh, W. C.; Liao, J. C. and Peng, W. C. (2005). Analgesic and anti-inflammatory activities of [6]-gingerol. J. Ethnopharmacol., 96: 207-210.

Zancan, K. C.; Marques, M. O.; Petenate, A. J. and Meireles, M. A. (2002). Extraction of ginger (Zingiber officinale Roscoe) oleoresin with $\mathrm{CO} 2$ andco-solvents: a study ofthe antioxidant action of the extracts. J. Supercrit. Flu., 24(1): 57-76.

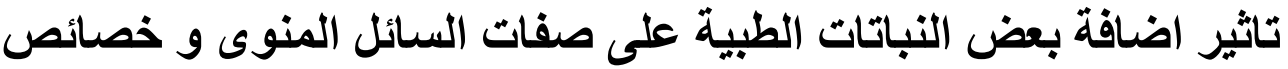

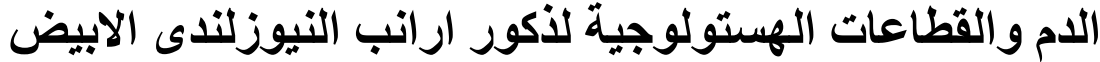
فى شمال سيناء

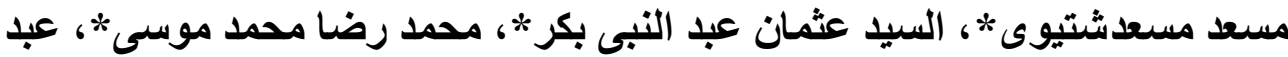

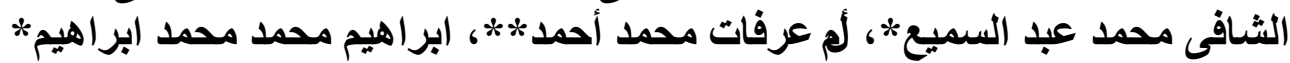

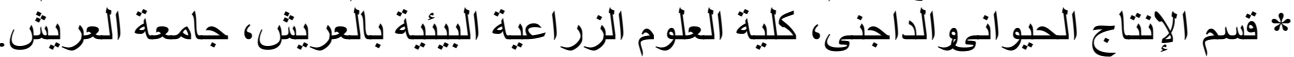

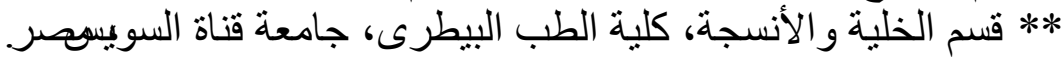

$$
\text { ذكور الأرانب النيوزيلندى الأبيض (عر } 9 \text { شهور وبمنوسطوزن }
$$

غ3,280.1 غذيت على خمسة علائق تجريبية متو ازنة حتى الثبع. العلى التيقة الأولى كنترول بدون

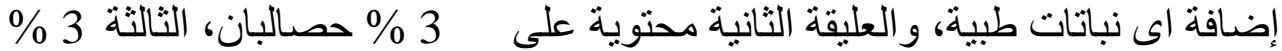

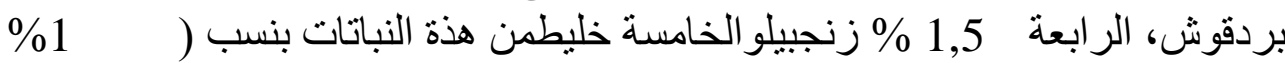

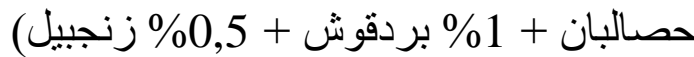

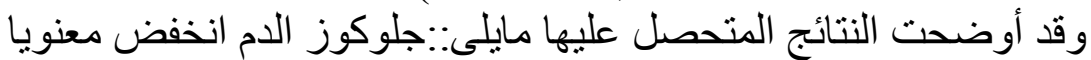

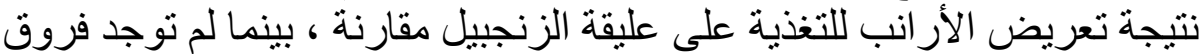

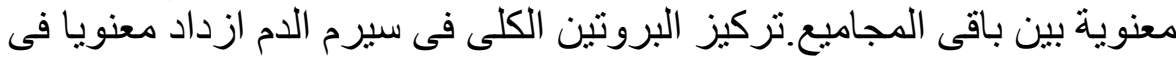

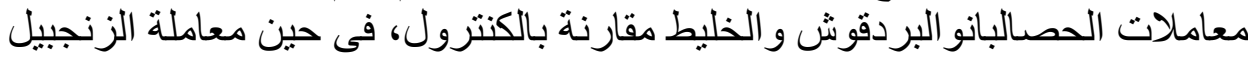

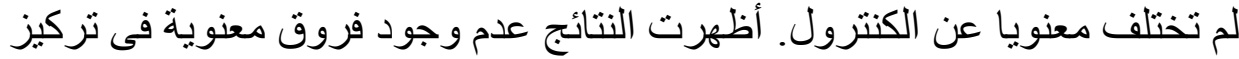

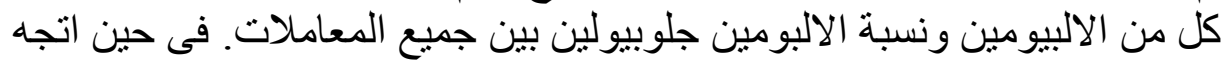

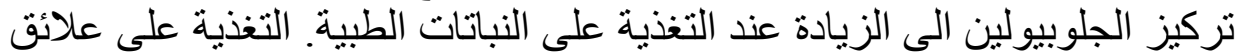

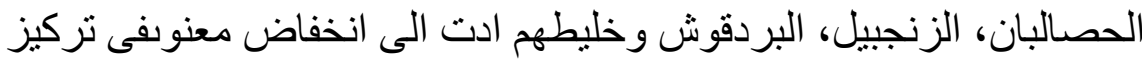

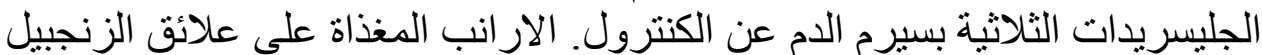

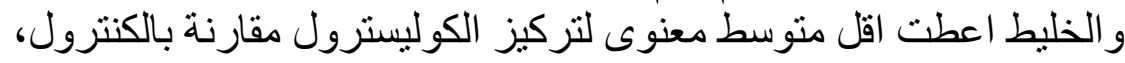


الحصالبان و البردقوش. ارتفع مستوى هرمون التستوسنيرون معنويا بصورة مرتفعة

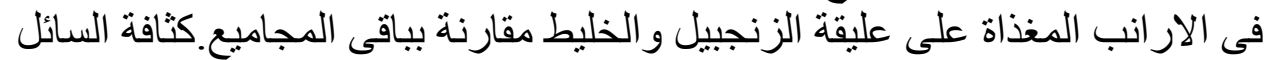

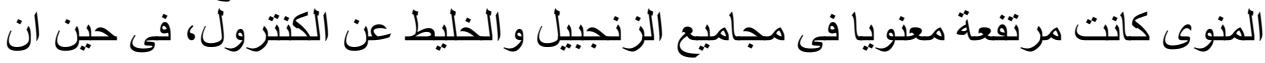

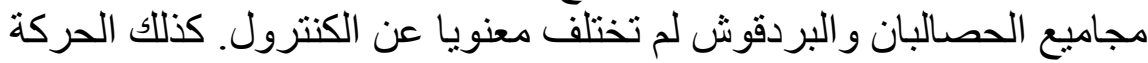

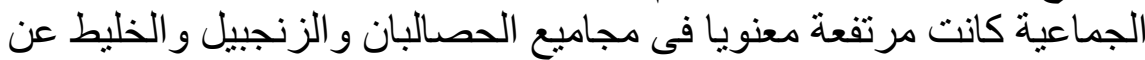

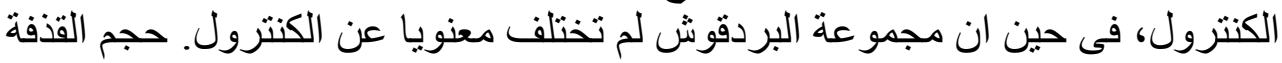

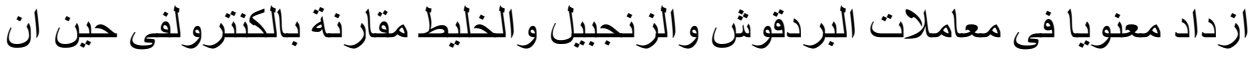

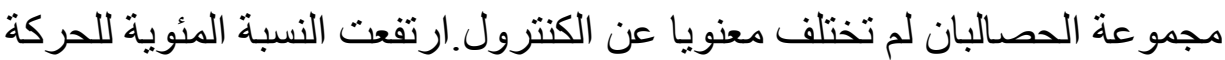

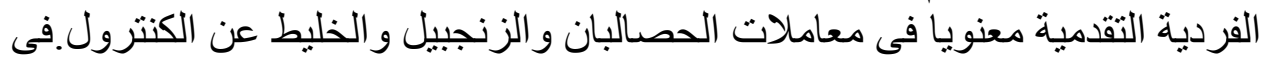

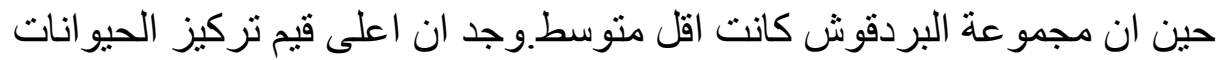

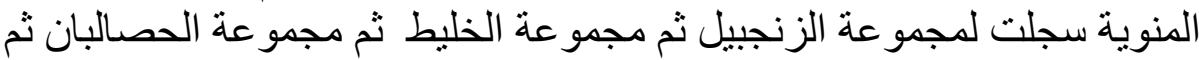

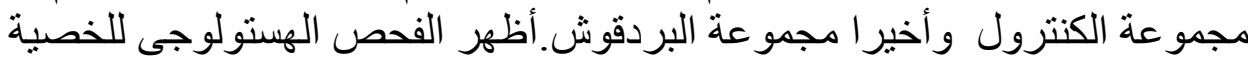

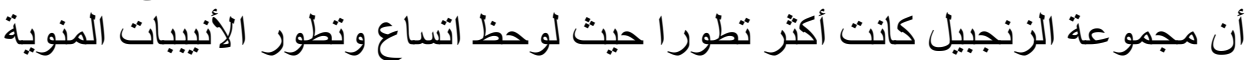

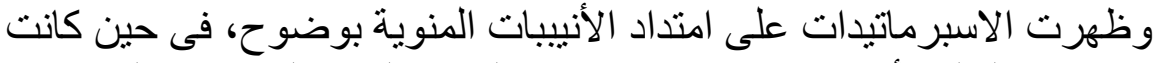

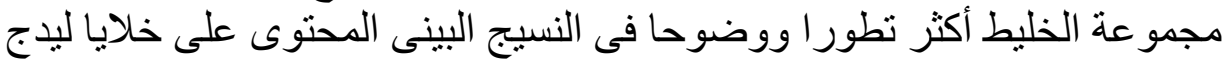

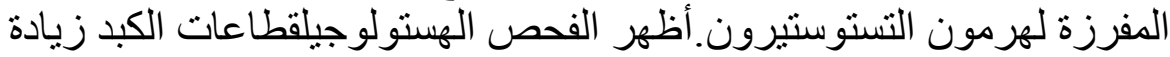

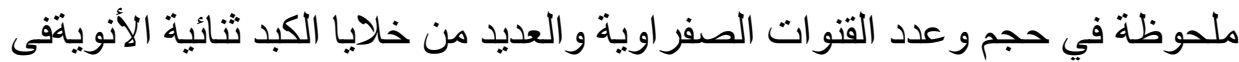

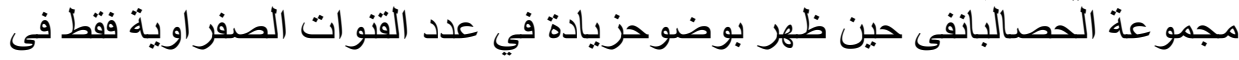

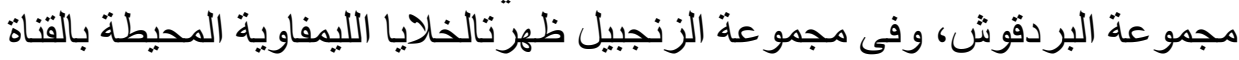

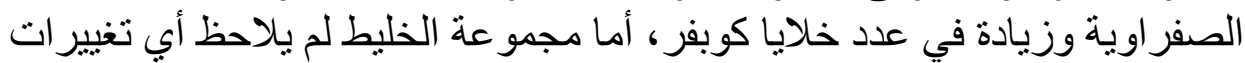

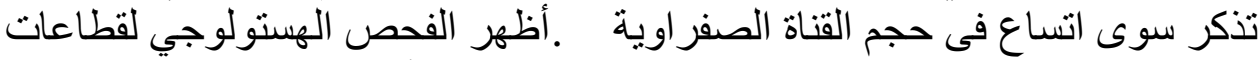

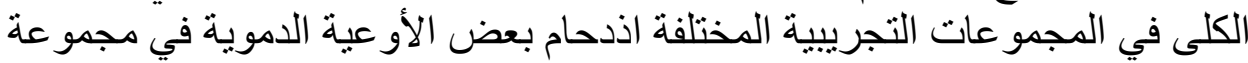

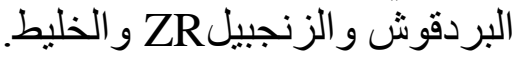

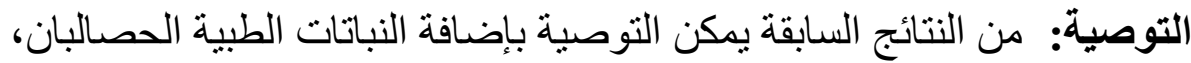

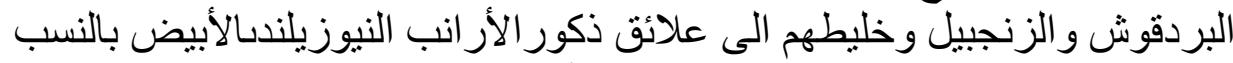

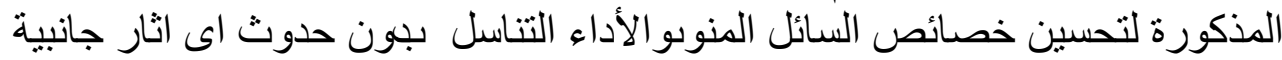

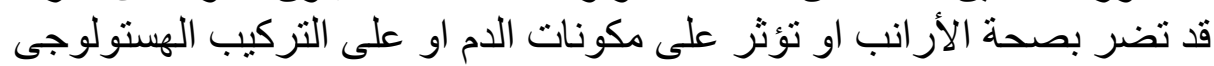

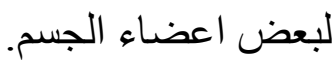

